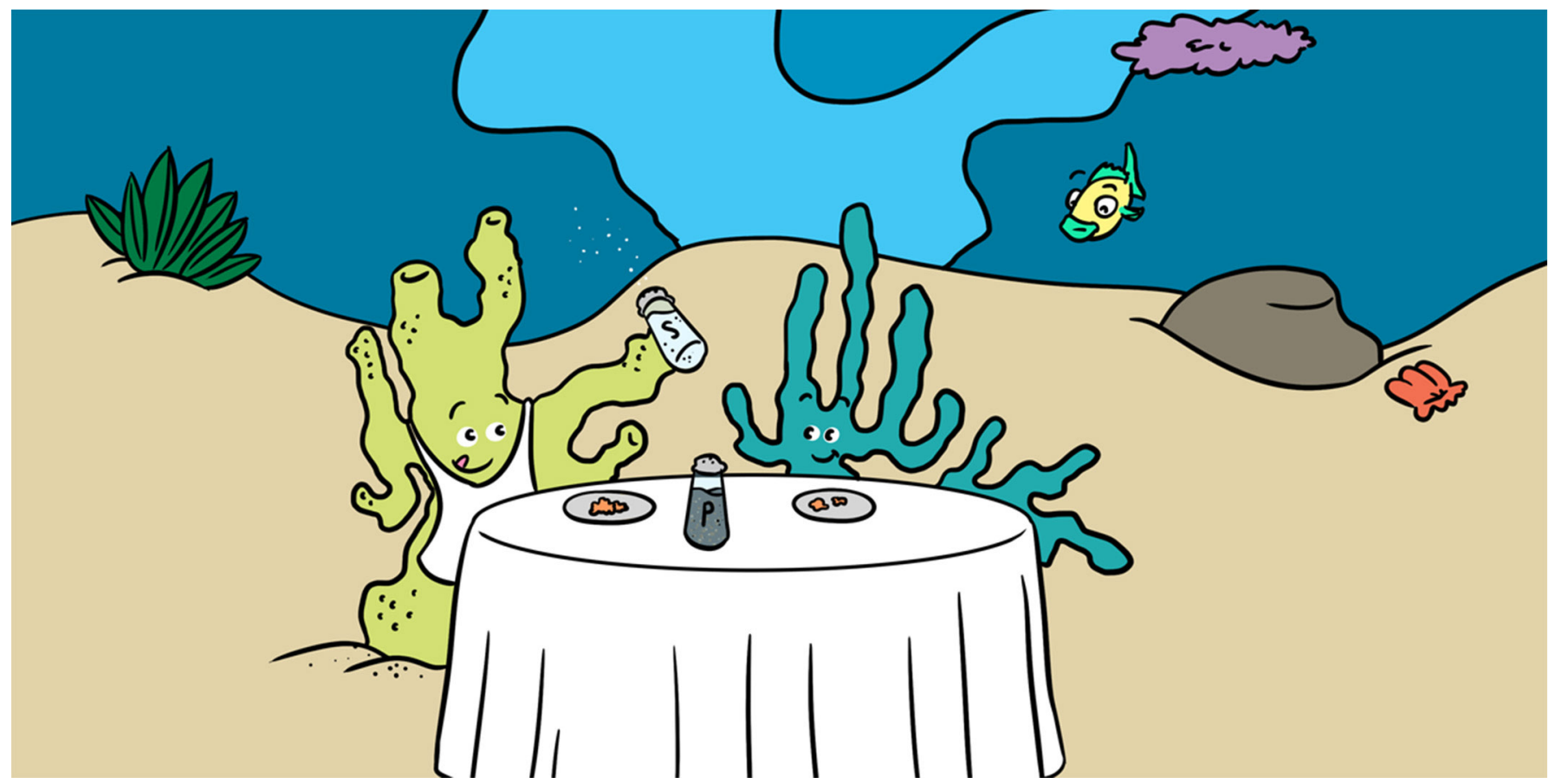

\title{
A SALTY CORAL SECRET: HOW HIGH SALINITY HELPS CORALS TO BE STRONGER
}

\section{Hagen M. Gegner* and Christian R. Voolstra}

Division of Biological and Environmental Science and Engineering, Red Sea Research Center, King Abdullah University of Science and Technology, Thuwal, Saudi Arabia

YOUNG REVIEWERS:

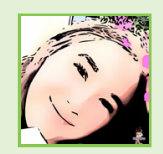

SAVANA

AGE: 13

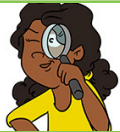

KAREN

AGE: 12

MALSHI

AGE: 12

YOUSSEF

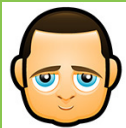

AGE: 12

ZIA

AGE: 12
Corals are mysterious animals that have been around for ages. They are the creators of beautiful reefs. Sadly, the reefs that we love to look at are in danger of overheating and are disappearing from our planet. While this sounds bad, not all corals are affected the same way by warm seawater. Corals from the Red Sea seem to be more resistant to higher temperatures than are corals from other regions. Red Sea reefs are thriving in seawater that is hotter than that in other places. But what is their secret? What makes Red Sea corals stronger and more heat resistant? We know that Red Sea corals not only handle the incredibly high temperatures, but also deal with high salinity (saltiness). This connection between high salinity and high temperature made us wonder: can we find evidence that high salinity makes corals stronger? 


\section{ANCIENT CREATURES IN DANGER OF OVERHEATING}

Reefs are incredibly colorful, fascinating underwater structures. They are created by some of the world's oldest animals: corals. Corals have been around since the time of the dinosaurs, but unlike those famous creatures, corals did not go extinct. At least not yet.

This impressive survival track record is in danger, due to stressful environmental conditions that make it hard for corals to survive in today's oceans. The biggest problem corals are facing is the quickly rising ocean temperature.

Global Ocean warming leads to the whitening of corals around the world, a phenomenon that is known as coral bleaching [1]. But what is coral bleaching and why is it bad for corals?

When we think of animals, we generally think of them as individuals, like a dog or a lion or a fish. But corals are different. Corals live together

\section{Figure 1}

The surprisingly similar tissue of corals and anemones. You can see the very simple cell layering of corals and Aiptasia, the coral model organism, in orange (outer and inner cell layer) and the in-between jelly in green. The algae symbionts are shown in brown and live inside the inner cell layer. They can be found in Aiptasia as well as corals.

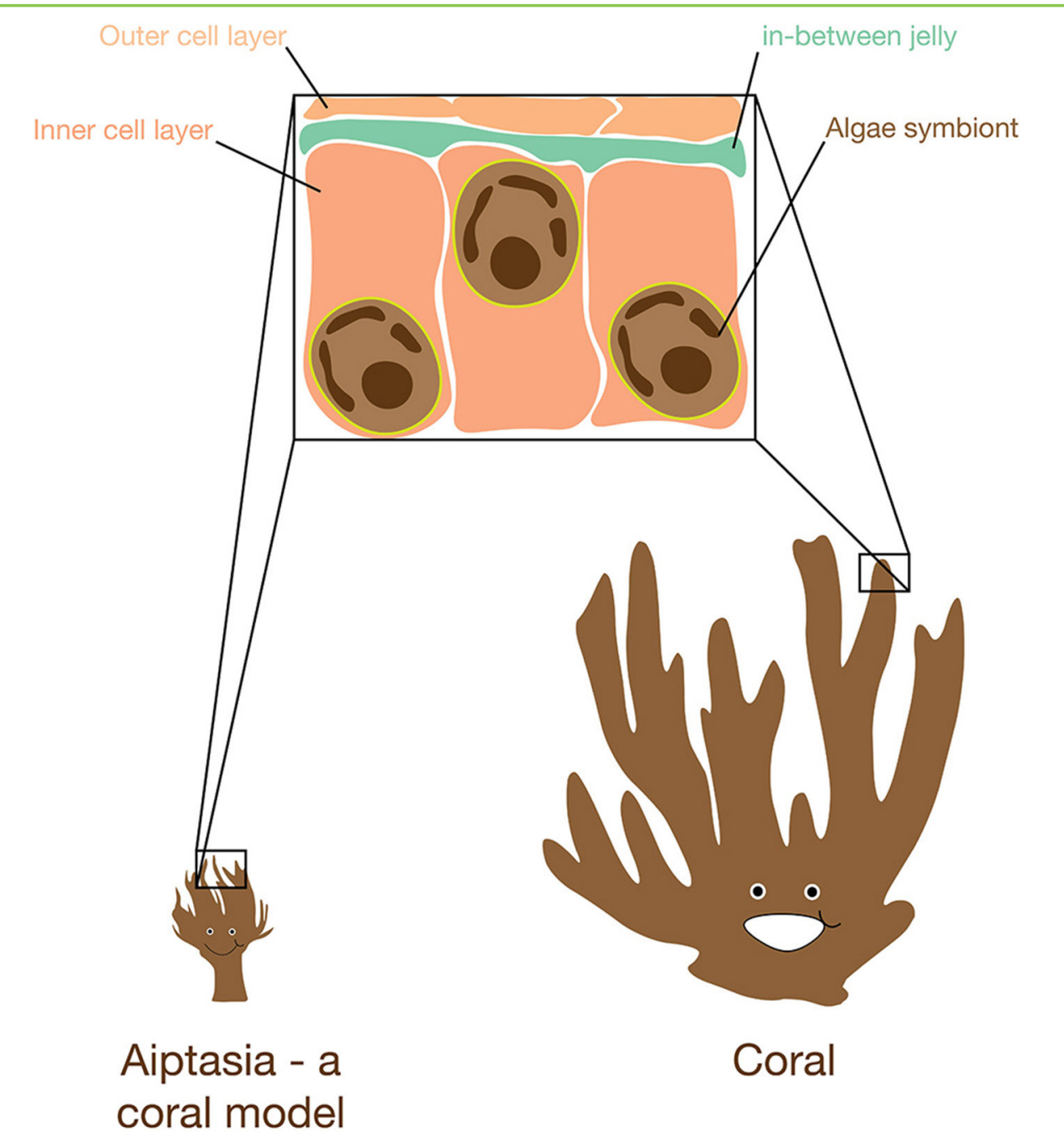

Figure 1 


\section{ALGAE}

Plants that live in the water. They do not flower like land plants and have no roots or stems. You can find them as single cells, for examples, in corals and anemones.

\section{ANEMONE}

A close relative of the coral. They have the same structure and live the same way as corals, but are squishier, because they have no skeletons.

\section{SYMBIOSIS}

A close relationship in which two living things work together, e.g., algae and the coral or anemone.

\section{SALINITY}

The amount of salt in water, for example, in seawater. You can find a range of different salinities in the ocean, depending on the region. The Red Sea has some of the highest levels of salt. with plants, tiny algae that provide food and in return are allowed to live inside the tissue, the inner cell layer, of corals or anemones (Figure 1) [2]. This type of teamwork and close relationship is called symbiosis and the partners involved in it, the coral and the algae in this case, are called symbionts. Algae symbionts can perform photosynthesis, a process you may have heard about that plants use to transform sunlight into energy. In our coral symbiosis, the energy coming from all algae symbionts becomes food for the corals. The algae also provide the beautiful colors we see when we look at coral reefs, because corals themselves are colorless.

Corals faced with difficult environmental conditions, for example, high water temperatures, experience the breakdown of this symbiosis. This results in the loss of their colorful algae friends within them, leaving only the see-through coral tissue on the white coral skeleton-a bleached coral. This bleached coral will no longer have the benefit of the additional food provided by the algae, which makes life hard for them. But not all corals are bleaching at the same level. They bleach at different temperatures, depending on the type of corals or algae, and where they live. To understand how bleaching works, we looked at the strongest corals we could find: Red Sea corals.

\section{THE RED SEA: ONLY FOR THE STRONGEST}

When we look at the Red Sea, we can find corals that are more resistant to bleaching than other corals worldwide. But why is that?

Corals in the Red Sea have to handle higher temperatures, yet they seem to grow and do just fine. The Red Sea is a very warm sea compared to other places. There, summer temperatures can reach up to $34^{\circ} \mathrm{C}$, while other ocean waters may reach around $29-32^{\circ} \mathrm{C}$. Interestingly, corals in the Red Sea are not only living in higher temperatures but also in higher salinity. Salinity is a measure of the amount of salt in the water, and the Red Sea has some of the world's highest salt levels. That is why we started wondering whether salinity could be a piece of the puzzle and the ability to live in high salinity one of the secrets of the strong Red Sea corals?

To answer this and other questions related to coral bleaching, scientists often use a coral model organism, which means an animal that is easier to study than corals but at the same time is very similar to corals. Meet Aiptasia! (Figure 1).

Aiptasia is a tiny anemone that shares a similar body structure with corals but lacks the skeleton. Aiptasia also has the same symbiosis with algae 
that corals have. Aiptasia and corals are closely related and live in similar ways. Besides that, Aiptasia has the advantage that it can be kept in the laboratory and is easy to care for [3]. In contrast, corals need a lot of care. They need big aquarium tanks with lots of technology inside to keep them alive and bringing corals from the reef to the laboratory can be very challenging as well. This makes corals hard to study.

\section{DOES HIGH SALINITY MAKE A DIFFERENCE DURING BLEACHING?}

To find out if salinity affects the symbiosis of Aiptasia and its algal symbionts, we thought of an experiment. Aiptasia were kept in three different levels of salinity: low, medium, and high, at a control temperature of $25^{\circ} \mathrm{C}$. This temperature is known to be the best for anemones without creating any additional stress. After they got used to their level of salinity, half of the anemones from each salinity level were put under heat stress, by increasing the temperature to $34^{\circ} \mathrm{C}$, a temperature that resulted in bleaching. To measure how much the Aiptasia in each group bleached, we counted the algal symbionts living in them. Since bleaching is a visible process (causing see-through vs. brown anemones), we also took pictures to illustrate our results.

After 8 days of heat stress, we looked at our anemones and investigated whether salinity affected how much they bleached. Looking at Figures 2A,B, do you see differences between the anemones in the low, medium, and high salinity after the heat stress?

Indeed, the pictures reveal that anemones that experienced heat stress in the low salinity condition were completely see-through. Compare that with the brownish anemone in the highest salinity level. It seems that there is a difference in the amount of bleaching seen between the different salinities. But wait, pictures can fool us! To measure if our impression was correct, we counted the number of algal cells that were inside the anemones. The bar graph in Figure 2C shows the percentage of algal cells that are still present after heat stress, compared with our control Aiptasia: $100 \%$ would mean that the anemone did not bleach, $0 \%$ that the anemone bleached completely, and no algae were left. The percentages we calculated from counting the algae confirmed what our eyes told us already. Low salinity anemones bleached more (only $13.6 \%$ algae remaining) than higher salinity anemones (30.5 and 37.2\% algae remaining).

But what is happening inside the anemones when they are in high salinity to create such an effect? 
Figure 2

The different effects of salinity during bleaching. Here you see the differences between low, medium, and high salinity on our anemones, after heat stress. (A) A cartoon view of the color of Aiptasia. (B) Photos of Aiptasia in each condition. The view is from the top. You can see the mouth region and the tentacles.

(C) A bar graph showing the counted numbers of algae that are still in the anemone after eight days of heat stress. The fact that all the bars are below $100 \%$ means that all anemones bleached, but those living in high salinity bleached less.

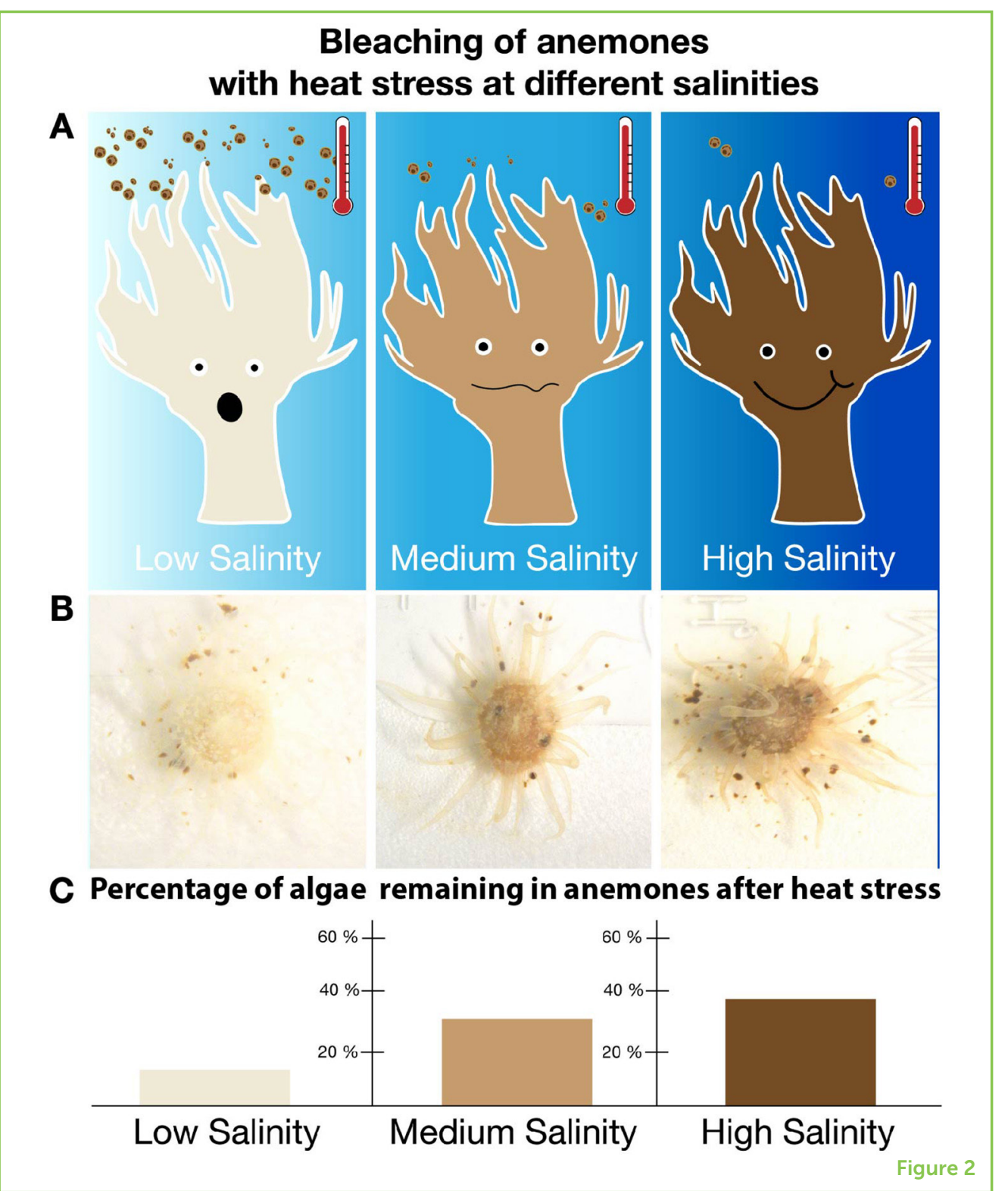

EXPLODING CHERRIES AND SALTY CORALS

Before we talk about what happens with our tiny anemone in high salinity, let us talk about cherries. Yes, cherries-red, sweet, delicious cherries.

If you are lucky enough to have a cherry tree at home with some cherries on it, you may want to check on them after the next heavy rain. Why? Because you will see that some of the cherries will be cracked open (Figure 3A), even though they were perfectly fine before the rain! You may be wondering how rain can crack open cherries and what this has to do with anemones. The answer has to do with the fact that cherries are sweet and with something called osmosis. 
Figure 3

The story of the bursting cherry.

(A) Cherries crack open after rain due to the difference in the amount of sugar between the inside of the cell and the outside. (B) Osmosis is the movement of water from an area with a low concentration of a molecule to an area with a higher concentration. In this case, the water moves from a low amount of sugar outside the cell (right) to a high amount inside the cell (left). The sugar is shown in red, the water in blue, and the white arrow shows the movement of the water.

\section{OSMOLYTE}

A molecule that is involved in the adjustment to salinity. They are produced or broken down to help reduce the salt difference between the inside of a cell and the outside.

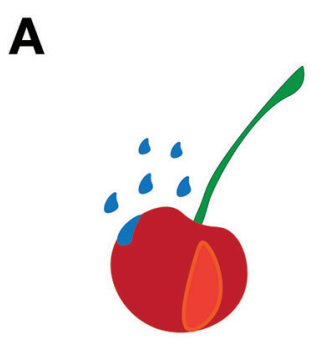

\section{B Osmosis}

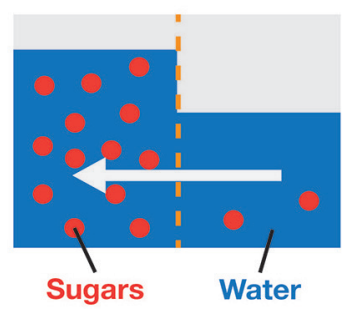

Figure 3

Osmosis is the movement of water from an area where there is a low amount of a substance, for example sugar, to an area where there is a higher amount (Figure 3B). If you think about the cracked cherry, this means that the water from the rain moved from outside the cherry, where there was no sugar, to the inside of the sugary cells, filling up the cells until they burst. The difference in the amount of sugar between inside and outside of the cherry is what moves the water. Osmosis plays a role in many things, not only the cracking of cherries. Osmosis also plays a role in what happens to our anemones!

Anemones and corals live at different salinities, but they never break open when the salinity changes. Even if you move an anemone from high salinity to low salinity in our experiment, it will not burst like the cherries. Why is that? It is because corals and anemones do not have a difference in the salinity inside their cells compared with the seawater [4]. Corals and anemones produce and break down molecules that are called osmolytes, in order to adjust their cells to the seawater environment. That way, they can keep the salinity the same both inside and outside their cells. No difference in salinity means no water movement. That way, these animals do not suffer the same fate as the cherries.

So, this means that the anemones in the high salinity condition in our experiment had to increase the amount of osmolytes in their cells, to adjust to the amount of salt outside the cells. This gave us a hint that the production of osmolytes may be connected to the lesser degree of bleaching that we see in certain corals. What it is exactly about the osmolytes that help the coral survive in warm water we cannot say from the results of our experiment. But we know from other experiments that osmolytes sometimes live a double life in cells. They are not only important for salinity adjustments, but also help reduce the amount of other dangerous molecules that can damage the cells. These dangerous molecules are also linked to coral bleaching [5]. A reduction in these dangerous molecules due to the production of osmolytes may explain why the anemones in high salinity are more resistant to bleaching, compared with the anemones in low salinity. 


\section{IN A NUTSHELL}

By experimenting with our tiny anemones, we were able to uncover the fact that water salinity somehow affects anemone bleaching. We showed that high salinity reduced bleaching during heat stress. This information is also useful for corals, since Aiptasia and corals are very similar. The exact process that is behind this effect is still mysterious, but we are on the right track to understanding it better. Our next experiments will test this high salinity effect in corals from the Red Sea. Here, corals live in conditions with naturally high salinity and are also known to be resistant to bleaching. What happens when corals from the Red Sea are put into conditions of low salinity? Do you have an idea? We surely will find out-stay tuned!

\section{ORIGINAL SOURCE ARTICLE}

Gegner, H. M., Ziegler, M., Rädecker, N., Buitrago-López, C., Aranda, M., and Voolstra, C. R. 2017. High salinity conveys thermotolerance in the coral model Aiptasia. Biol. Open 6:1943-8. doi: 10.1242/bio.028878

\section{REFERENCES}

1. Hughes, T. P., Barnes, M. L., Bellwood, D. R., Cinner, J. E., Cumming, G. S., Jackson, J. B. C., et al. 2017. Coral reefs in the Anthropocene. Nature 546:82-90. doi: 10.1038/nature22901

2. Rohwer, F., Seguritan, V., Azam, F., and Knowlton, N. 2002. Diversity and distribution of coral-associated bacteria. Mar. Ecol. Prog. Ser. 243:1-10. doi: $10.3354 /$ meps 243001

3. Baumgarten, S., Simakov, O., Esherick, L. Y., Liew, Y. J., Lehnert, E. M., Michell, C. T., et al. 2015. The genome of Aiptasia, a sea anemone model for coral symbiosis. Proc. Natl. Acad. Sci. U.S.A. 112:11893-8. doi: 10.1073/pnas. 1513318112

4. Röthig, T., Ochsenkühn, M. A., Roik, A., Van Der Merwe, R., and Voolstra, C. R. 2016. Long-term salinity tolerance is accompanied by major restructuring of the coral bacterial microbiome. Mol. Ecol. 25:1308-23. doi: 10.1111/ mec.13567

5. Ochsenkühn, M. A., Röthig, T., D'Angelo, C., Wiedenmann, J., and Voolstra, C. R. 2017. The role of floridoside in osmoadaptation of coral-associated algal endosymbionts to high-salinity conditions. Sci. Adv. 3:e1602047. doi: 10.1126/ sciadv.1602047

SUBMITTED: 20 November 2018; ACCEPTED: 18 February 2019; PUBLISHED ONLINE: 07 March 2019. 
EDITED BY: Rúben Martins Costa, King Abdullah University of Science and Technology, Saudi Arabia

CITATION: Gegner HM and Voolstra CR (2019) A Salty Coral Secret: How High Salinity Helps Corals to be Stronger. Front. Young Minds 7:38. doi: 10.3389/ frym.2019.00038

CONFLICT OF INTEREST STATEMENT: The authors declare that the research was conducted in the absence of any commercial or financial relationships that could be construed as a potential conflict of interest.

COPYRIGHT @ 2019 Gegner and Voolstra. This is an open-access article distributed under the terms of the Creative Commons Attribution License (CC BY). The use, distribution or reproduction in other forums is permitted, provided the original author(s) and the copyright owner(s) are credited and that the original publication in this journal is cited, in accordance with accepted academic practice. No use, distribution or reproduction is permitted which does not comply with these terms.

\section{YOUNG REVIEWERS}

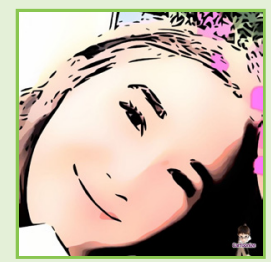

\section{SAVANA, AGE: 13}

I love dogs, my favorite color is red, and I love hanging out with my friends.

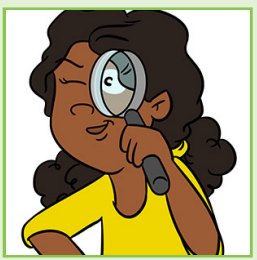

\section{KAREN, AGE: 12}

I am a very creative girl. My hobbies are sports and studying, and anything to do with art. I really like to try new things and explore things that I find interesting. I say that I am very unique, unlike other people. That is just what makes me, me!

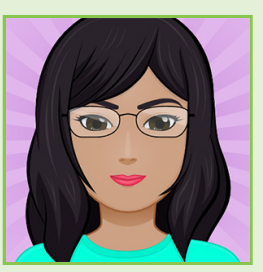

\section{MALSHI, AGE: 12}

My name is Malshi, and I am 12 years old. I like Science and Math and I am interested in Chemistry. I love reading in my spare time and I love playing the piano. My favorite sport is badminton and in the future, I want to be a scientist.

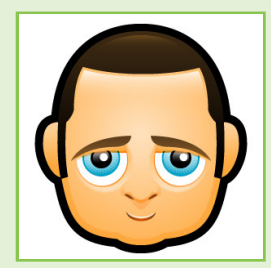

\section{YOUSSEF, AGE: 12}

I am a runner, swimmer, love to study, and read books. I especially love to read books. I chose Frontiers for Young minds because I wanted two things. My name on an official website! I wanted challenge. As an average seventh grader, I wanted to push myself in knowing new facts regarding science. And now that this is finished, I do not have the same knowledge when I started, than I have now. Thank you Frontiers for Young Minds!! (:) 


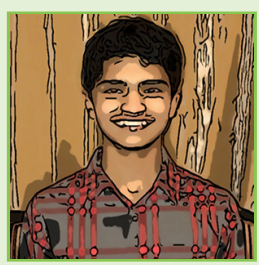

\section{ZIA, AGE: 12}

One of my favorite subjects in school is Science. I am very curious about how the daily things we do in our life happen. I especially like Biology and Cosmology. I watch a lot of documentaries about space and like to research on my interests.

\section{AUTHORS}

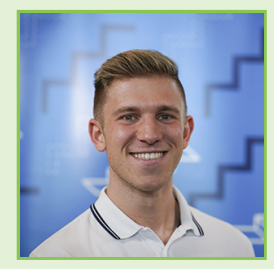

\section{HAGEN M. GEGNER}

I was always fascinated by the ocean and loved to explore reefs, but I never thought that I would call myself a Coral Biologist one day. I started out studying General Biology (B.SC.), after which, I slowly moved closer to Marine Sciences. In the end I was rather curious about the methods used than a single organism in research. So I continued working on fish in Brazil (M.Sc.) and recently, I finished my Ph.D. in Saudi Arabia in which I researched what makes corals stronger during stress. *hagen.gegner@akaust.edu.sa

\section{CHRISTIAN R. VOOLSTRA}

I started out studying the development of fruit flies and how the house mouse adjusts to different environments, before diving into coral biology. Nowadays, I, and many other researchers with me, are beginning to understand that all animals and plants team up with tiny living organisms, so-called microbes or bacteria, to digest food, stay healthy, and fight stress. In my lab, we study the different types of bacteria that live with corals and how they help their animal host to survive under stress. 